\title{
'Usyūr dan Jizyah dalam Kajian Ekonomi Islam
}

\author{
Nurul Hidayati \\ Institut Agama Islam Negeri Kudus \\ nuru1080582@gmail.com
}

\begin{abstract}
Fiscal policy is a policy pursued by the government in managing state income and expenditure. The state of Medina which was led by Muhammad SAW also had a unique fiscal policy system in his day. The implementation of fiscal policy at the time of the Prophet Muhammad and Abu Bakr was almost the same, because there were not many problems that emerged along with the expansion of the territory of the Islamic Caliphate. Sources of state revenues in the early days of Islam included the zakat, khums, jizyah, fai, 'usyür and other sources of income. One of the state revenues in the early days of Islam was 'usyür and jizyah. The discussion of 'usyur revolves around the definition, who is obliged to pay

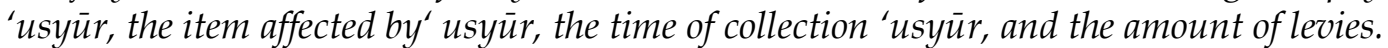
As for jizyah, the discussion revolves around the definition, the jizyah payer, the large number of levies, the termination of jizyah, the rights and obligations of Ahlu Zhimmah, the use of jizyah, orientalist criticism of jizyah, and then analyzing both. The policies exemplified by the Prophet Muhammad both legal, political and economic issues became guidelines for the Khulafa ar-Rashidin, his tireless friends always accompanied him. Among the policies relating to the economy are the collection of usyūr and jizyah. 'Usyūr and jizyah are one of the sources of income at the beginning of Islam which is quite important for state finance. This policy is also used by followers in managing the economic life of the country.
\end{abstract}

Keywords: 'usyur, jizyah, islamic economy

\begin{abstract}
Abstrak
Kebijakan fiskal adalah kebijakan yang di tempuh pemerintah dalam mengelola pemasukan dan pengeluaran negara. Negara Madinah yang di pimpin Muhammad SAW juga memiliki sistem kebijakan fiskal yang unik di zamannya. Pelaksanaan kebijakan fiskal pada masa Rasulullah SAW dan Abu Bakar hampir sama, karena belum banyak persoalan yang muncul seiring dengan perluasan wilayah kekuasaan kekhalifahan Islam. Sumber-sumber penerimaan negara pada masa awal Islam antara lain berasal dari zakat, khums, jizyah, fai, 'usyūr dan sumber-sumber penerimaan lainnya. Salah satu penerimaan negara pada masa awal Islam adalah 'usyūr dan jizyah. Pembahasan mengenai 'usyūr berkisar tentang definisi, siapa yang wajib membayar 'usyūr, barang yang terkena 'usyūr, waktu pemungutan 'usyūr, dan besarnya jumlah pungutan. Adapun jizyah pembahasannya seputar definisi, pihak pembayar jizyah, besarnya jumlah pungutan, penghentian jizyah, hak dan kewajiban bagi ahlu Zhimmah, penggunaan jizyah, kritik orientalis tentang jizyah, dan kemudian menganalisa keduanya. Kebijakan-kebijakan yang dicontohkan Rasulullah SAW baik masalah hukum, politik juga ekonomi menjadi pedoman bagi Khulafa ar-Rasyidin, para sahabatnya yang tak kenal lelah selalu mendampingi beliau. Di antara kebijakan yang berkaitan dengan ekonomi adalah pemungutan 'usyūr dan jizyah. 'Usyūr
\end{abstract}


dan jizyah adalah salah satu sumber pendapatan pada awal Islam yang cukup penting untuk keuangan negara. Kebijakan ini juga digunakan oleh pengikutnya dalam menata kehidupan ekonomi negara.

Kata Kunci: 'usyur, jizyah, ekonomi Islam

\section{PENDAHULUAN}

Pemikiran ekonomi Islam diawali sejak Rasulullah SAW dipilih sebagai seorang Rasul. Rasulullah SAW mengeluarkan sejumlah kebijakan yang menyangkut berbagai hal yang berkaitan dengan masalah kemasyarakatan, selain masalah hukum, politik, juga masalah perniagaan atau ekonomi. Masalah-masalah ekonomi umat menjadi perhatian Rasulullah SAW, karena masalah ekonomi merupakan pilar penyangga keimanan yang harus diperhatikan. (Sudarsono, 2007; 117) Salah satu masalah ekonomi adalah kebijakan mengenai fiskal (pendapatan negara).

Kebijakan fiskal adalah kebijakan yang di tempuh pemerintah dalam mengelola pemasukan dan pengeluaran negara. Negara Madinah yang di pimpin Muhammad SAW juga memiliki sistem kebijakan fiskal yang unik di zamannya. Pelaksanaan kebijakan fiskal pada masa Rasulullah SAW dan Abu Bakar hampir sama, karena belum banyak persoalan yang muncul seiring dengan perluasan wilayah kekuasaan kekhalifahan Islam. Sumbersumber penerimaan negara pada masa awal Islam antara lain berasal dari zakat, khums, jizyah, fai, 'usyūr dan sumber-sumber penerimaan lainnya. (Muhammad, 2007; 167)

Salah satu penerimaan negara pada masa awal Islam adalah 'usyūr dan jizyah. Pembahasan mengenai 'usyūr berkisar tentang definisi, siapa yang wajib membayar 'usyūr, barang yang terkena 'usyūr, waktu pemungutan 'usyūr, dan besarnya jumlah pungutan. Adapun jizyah pembahasannya seputar definisi, pihak pembayar jizyah, besarnya jumlah pungutan, penghentian jizyah, hak dan kewajiban bagi ahlu Zhimmah, penggunaan jizyah, kritik orientalis tentang jizyah, dan kemudian menganalisa keduanya.

\section{PEMBAHASAN TENTANG ‘USYŪR Definisi ‘Usyūr}

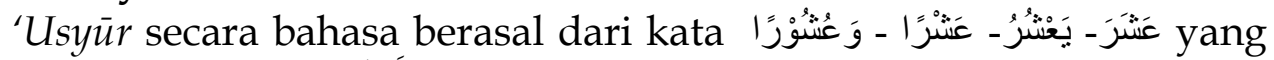

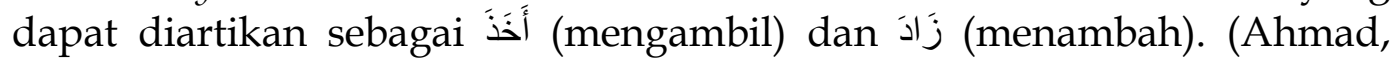
1997; 932) Sedang secara istilah adalah harta perdagangan yang di ambil dari kaum Zimmah dan kaum Harbi yang melewati perbatasan negara Khilafah. Orang yang bertugas memungutnya di sebut 'A $\bar{s}$ syir (petugas bea cukai). (Abdul, 2002; 105) Dalam konteks perekonomian modern, 'usyūr identik dengan pajak ekspor-impor atau bea cukai. 


\section{Jumlah Pungutan dan Pihak Pembayar 'Usyūr}

Umar RA menentukan pedagang yang di ambil 'usyūr, di mana Ziyad bin Hudair meriwayatkan, "Bahwa Umar bin Al-Khattab mengutusnya dalam masalah 'usyūr ke Irak dan Syam, dan memerintahkannya untuk mengambil 2.5\% dari kaum Muslim, 5\% dari kaum Z | immi, dan 10\% dari kafir Harbi". (Jaribah, 2006; 570)

Dari riwayat tersebut dapat dibedakan antara tiga kelompok pedagang yaitu pedagang Muslim, pedagang dari kalangan ahlu Zhimmah, dan pedagang dari kelompok ahlu Harbi. Dimana hakikat yang di ambil dari masing-masing kelompok dapat dijelaskan sebagai berikut:

Pertama: Pedagang Muslim

Terdapat beberapa hadis yang menunjukkan tidak bolehnya pengambilan 'usyūr dari pedagang muslim, di mana hadis yang paling sahih adalah yang diriwayatkan Imam Muslim dan yang lainnya dalam kisah seorang wanita yang berzina, kemudian bertaubat dan dilaksanakannya hukum had kepadanya, lalu Nabi SAW bersabda,

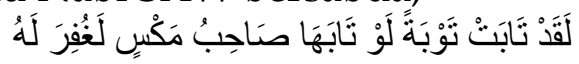

"Sesungguhnya dia telah bertaubat, yang jika petugas pajak bertaubat sepertinya niscaya dia akan diampuni oleh Allah".

Dalam hadis lain disebutkan,

"Tidak masuk surga petugas pajak".

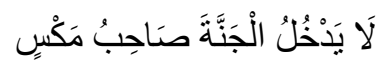

Di mana ulama menafsirkan bahwa petugas pajak ini adalah "Orang yang mengambil 'usyūr dari harta kaum Muslimin; di mana ia mengambil secara paksa dari pedagang Muslim jika melintasi daerahnya dengan mengatasnamakan 'usyūr, dan bukan petugas yang mengumpulkan zakat. Adapun 'usyūr yang di ambil dengan kesepakatan dari dagangan orangorang yang memiliki perjanjian dagang dengan negara Islam, maka itu bukanlah bentuk pemaksaan, dan petugasnya tidak berhak mendapatkan ancaman tersebut; kecuali jika dia melampaui batas dan zalim, maka dikhawatirkan dosa dan sanksi baginya".

Sebagaimana juga terdapat beberapa riwayat yang menunjukkan dilarangnya mengambil 'usyūr dari seorang muslim dan kafir Zhimmi, diantaranya adalah perkataan Ziyad bin Hudair kepada Umar RA, "Kami dahulu tidak mengambil 'usyūr dari seorang muslim ataupun kafir Zhimmi". Umar berkata, "Lalu siapa yang kamu ambil 'usyūr-nya?" Ia menjawab, "Para pedagang dari ahlu Harbi, sebagaimana mereka mengambil 'usyūr kepada kami jika kami datang ke negeri mereka”. Dalam riwayat lain Ziyad berkata, "Dan dia melarangku mengambil 'usyūr kepada seorang Muslim, atau kafir Zhimmi yang menyerahkan kharāj".

Hal ini karena seorang muslim tidak diwajibkan membayar 'usyūr, dan tidak wajib pula membayar bea cukai atas barang dagangannya, 
kecuali membayar zakat, berupa 1/4 'usyūr atau 2.5\%. Dan ini bukanlah pajak atau 'usyūr penuh. Dengan demikian, jelas bahwa maksud dari hadis Ibnu Umar dan hadis Ziyad bin Hudair, bahwa Umar tidak memungut 'usyūr melainkan memungut zakat dagang dari kaum Muslim, dengan ketentuan $1 / 4$ 'usyū $r$ bukan 'usyūr penuh.

Sedangkan jumlah zakat pertanian bagi seorang Muslim, Yahya mengatakan: "Segala yang diairi dengan air yang mengalir atau hujan dapat dikenai zakat 'usyr (sepersepuluh dari seluruh hasil), tetapi terhadap segala yang diairi dengan timba (dengan menggunakan kerja manual) bebannya adalah setengah 'usyr (seperduapuluh dari hasil). Jadi, zakat atas hasil pertanian ditetapkan sesuai dengan pekerjaan dan modal yang diperlukan untuk produksi. Karena itu, semakin sedikit pekerjaan dan modal yang diperlukan jumlah pajaknya tinggi dan sebaliknya. Dalam kasus hasil pertanian, perbedaan dilakukan dalam sistem irigasi, jadi pertanian yang diairi dengan air alamiah dikenai zakat yang tinggi, sementara kerja manusia yang dibutuhkan dalam irigasi, bebannya rendah. (Sabahudin, 2005; 99)

Kedua: Pedagang Ahlu Zhimmah

Para ulama berbeda pendapat dalam hal ini, di mana ulama Syafi'iyah dan Ibnu Hazm berpendapat tentang haramnya pengambilan 'usyūr dari harta ahlu Zhimmah, selama tidak dipersyaratkan kepada mereka dalam akad perdamaian. Namun, ulama Syafi'iyah mengecualikan daerah Hijaz, di mana mereka memperbolehkan pengambilan 'usyūr dari dagangan ahlu Zhimmah yang masuk daerah Hijaz dengan membawa dagangan.

Madzhab Maliki berpendapat diperbolehkannya pengambilan ' usyūr terhadap dagangan kafir Zhimmi jika ia membawa dagangannya melewati batas daerah mukimnya. Tapi, jika ia berdagang di daerahnya, maka tidak ada kewajiban apapun terhadapnya. Sebagai contoh jika seorang kafir Zhimmi termasuk penduduk Syam, maka tiada wajib 'usyūr baginya jika ia berdagang dalam batas-batas daerah Syam. Tapi, jika keluar dengan dagangannya ke Mesir atau ke Irak maka di ambil 'usyūr darinya.

Ulama Hanafi dan ulama Hambali berpendapat diperbolehkannya pengambilan 'usyūr dari para pedagang ahlu Zhimmah secara mutlak, baik dia berdagang di daerah tinggalnya sendiri atau membawa dagangannya dari suatu daerah ke daerah lain. Adapun beberapa riwayat yang menunjukkan larangan pengambilan 'usyūr dari pedangang Muslim dan pedagang kafir Z|immi, maka Abu Ubaid berpendapat bahwa beberapa riwayat itu berarti bahwa mereka tidak di ambil 'usyūr secara penuh (10\%) sebagaimana yang di ambil dari ahlu Harbi. Namun, dari pedagang Muslim hanya seperempat dari 10\% (2.5\%), sedangkan dari ahlu Zhimmah setengah dari 10\% (5\%). (Jaribah, 2006; 572) 
Ketiga: Pedagang Ahlu Harbi

Hukum yang asal bagi para pedagang ahlu Harbi yang masuk ke wilayah kaum Muslimin untuk berdagang adalah di ambil pajak 10\% dari mereka; karena mereka mengambil 10\% dari para pedagang Muslim jika masuk ke daerah mereka untuk berdagang, sehingga Umar memerintahkan untuk memperlakukan hal yang sama terhadap para pedagang ahlu Harbi. Sebagaimana sebagian pedagang ahlu Harbi juga meminta dari kaum Muslimin agar diizinkan masuk ke wilayah Islam untuk berdagang dengan imbalan 10\%, maka Umar pun mengizinkan mereka setelah bermusyawarah dengan kaum Muslimin dan konsensus dalam hal tersebut.

Ahli Fikih hampir sepakat-secara global-tentang diperbolehkannya penetapan 'usyūr terhadap pedangan kafir Harbi, baik dia masuk dengan dagangan ke daerah kaum Muslimin, ataukah keluar darinya dengan dagangan. Akan tetapi, ulama Syafi'iyah dan Ibnu Hazm sebagaimana dalam kafir Zhimmi-berpendapat bahwa kafir Harbi jika masuk daerah Islam membawa dagangan, dengan kepastian keamanan, maka tidak boleh di ambil sesuatu pun darinya, selama hal tersebut tidak disyaratkan kepadanya dalam akad pengamanan.

\section{Barang yang Terkena 'Usyūr}

'Usyūr dipungut atas seluruh jenis barang dagangan. Apapun jenisnya, baik perhiasan, hewan, hasil pertanian, atau buah-buahan. 'Usyūr tidak di ambil dari selain barang dagangan. 'Usyūr tidak di ambil dari pakaian atau peralatan yang digunakan oleh seseorang untuk kegiatannya, atau kebutuhan sehari-hari, termasuk makanan. Jika ada seseorang yang mengadukan bahwa barang yang dibawanya itu bukan untuk diperdagangkan, padahal barang tersebut untuk diperdagangkan, maka (pernyataan tersebut) tidak di percaya kecuali dengan (menghadirkan) bukti-bukti, untuk memastikan kebenaran pengaduannya. (Abdul, 2002; 112)

'Usyūr tidak dipungut dari para pedagang Zhimmi dan penduduk golongan Harbi kecuali barang dagangan mereka melewati perbatasan negara. Demikian juga 'usyūr tidak diambil dari harta perdagangan mereka (yang diperdagangkan) di dalam negeri, kecuali ditetapkan di dalam perjanjian damai atau kesepakatan perdagangan dengan negara-negara lain.

\section{Waktu Pemungutan ‘Usyūr}

'Usyūr hanya dipungut satu kali dalam setahun untuk satu jenis barang dagangan, walaupun pedagang tersebut berkali-kali melewati 
perbatasan dengan barang dagangannya itu. Maka 'Āsyir tidak boleh memungut lebih dari satu kali. Dari Ibnu Ziyad bin Hudair mengatakan bahwa bapaknya mengambil 'usyūr dari orang Nasrani dua kali dalam setiap tahun, maka orang Nasrani tersebut mendatangi Umar bin Khattab dan berkata: "Wahai Amirul Mukminin sesungguhnya petugasmu mengambil 'usyūr dariku dua kali dalam satu tahun". Umar menjawab: "Dia tidak boleh melakukan hal itu. Yang boleh diambilnya hanya satu kali dalam satu tahun". Kemudian orang Nasrani tersebut mendatangi Umar untuk kedua kalinya seraya berkata: "Aku adalah pemimpin kaum Nasrani". Umar menjawab: "Aku adalah pemimpin yang lurus, sungguh telah aku catat pengaduanmu".

Adapun jika para pedagang dari golongan Zhimmi dan penduduk golongan Harbi melewati perbatasan lebih dari satu kali dengan jenis barang dagangan yang berbeda-beda, maka 'usyūr diambil dari mereka setiap kali melewati perbatasan. Demikian juga dari seorang Muslim di ambil zakatnya setiap melewati perbatasan dengan membawa barang dagangan yang berbeda.

Dan pada dasarnya ketentuan (besarnya) pungutan dari para pedagang kaum Zhimmi dan Harbi merupakan wewenang Khalifah. Ia berhak menambah atau menguranginya sesuai dengan kesepatakan damai yang telah ditetapkan atau yang akan ditetapkan. Juga sesuai dengan perlakuan seimbang, sebagaimana mereka memperlakukan para pedagang Muslim. (Abdul, 2002; 111)

\section{PEMBAHASAN TENTANG JIZYAH Definisi Jiyzah}

Kata jizyah berasal dari kata جَزَى - يَجْزِ - كَفَ yan yang berarti (mencukupi) dan عَاقَبَ (menghukum). Sedang menurut istilah yaitu sejumlah harta yang dibebankan pada orang yang berada di bawah tanggungan kaum Muslimin dan melakukan perjanjian dengan mereka (muslimin) dari Ahlul Kitāb. Jizyah adalah hak yang diberikan Allah kepada kaum Muslimin dari orang-orang kafir sebagai tanda tunduknya mereka kepada Islam. (Sayyid, 1999; 405) Apabila orang-orang kafir itu telah memberikan jizyah, maka wajib bagi kaum Muslim melindungi jiwa dan harta mereka. (Abdul Qadim, 1996; 258) Ketentuan jizyah ini berlandaskan firman Allah yang berbunyi:

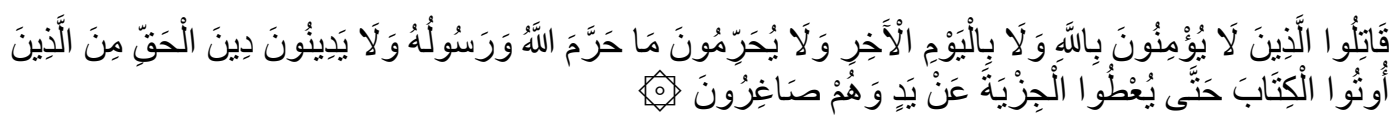

"Perangilah orang-orang yang tidak beriman kepada Allah dan tidak (pula) kepada hari Kemudian, dan mereka tidak mengharamkan apa yang diharamkan oleh Allah dan Rasul-Nya dan tidak beragama dengan agama yang benar (agama Allah), (yaitu orang-orang) yang diberikan al-Kitab kepada mereka, sampai mereka 
membayar jizyah dengan patuh sedang mereka dalam keadaan tunduk" (QS. AtTaubah: 29).

\section{Pihak Pembayar Jizyah}

Jizyah di ambil dari ahlu Kitab, yaitu orang-orang Yahudi dan Nasrani berdasarkan firman Allah SWT: مِنَ الَّذَينَ أُوتُو ا الْكَتَابَ " (yaitu orang-orang) yang diberikan al-Kitab kepada mereka" (QS. At-Taubah: 29). Baik itu orangorang Yahudi dan Nasrani Arab maupun orang-orang Yahudi dan Nasrani bukan Arab. Rasulullah SAW telah mengambil jizyah dari orang Yahudi Yaman dan dari orang Nasrani Najran. Dari 'Urwah bin Zubair, ia berkata bahwa Rasulullah SAW telah menulis surat kepada penduduk Yaman. Surat itu berbunyi:

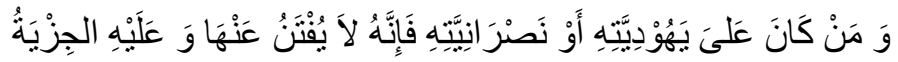

"Barangsiapa yang telah memeluk agama Yahudi atau Nasrani tidak ada fitnah baginya dan wajib baginya membayar jizyah".

Jizyah juga di pungut dari orang-orang selain ahlu Kitab seperti Majusi, Shābi'ah, Hindu dan orang-orang komunis, karena Rasulullah SAW telah mengambil jizyah dari orang Majusi Hajar. Bukhari dan Tirmizi meriwayatkan dari Abdurrahman bin 'Auf, bahwa Nabi SAW mengambil jizyah dari orang-orang Majusi Hajar. Dan Tirmizi meriwayatkan bahwa Nabi SAW memungut jizyah dari orang Majusi Bahrain dan Umar RA memungutnya dari orang Persia dan Usman memungutnya dari orang Persia dan Barbar.

Jizyah di ambil dari orang laki-laki yang sehat akalnya, mukallaf (sudah balig) dan merdeka. Ini berlandaskan firman Allah:

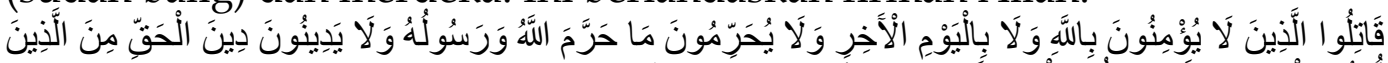

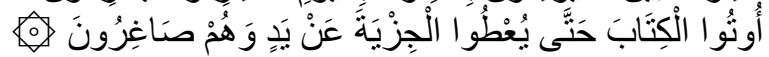

"Perangilah orang-orang yang tidak beriman kepada Allah dan tidak (pula) kepada hari Kemudian, dan mereka tidak mengharamkan apa yang diharamkan oleh Allah dan Rasul-Nya dan tidak beragama dengan agama yang benar (agama Allah), (yaitu orang-orang) yang diberikan al-Kitab kepada mereka, sampai mereka membayar jizyah dengan patuh sedang mereka dalam keadaan tunduk" (QS. AtTaubah: 29). Artinya, dari orang yang mampu dan kaya. Maka, jizyah tidak wajib atas wanita, anak kecil, hamba sahaya, dan orang gila. Sebagaimana juga jizyah tidak wajib bagi orang miskin yang perlu di beri sedekah, orang yang tidak mampu bekerja, orang buta, orang yang tidak bisa bangun dari tempat duduk dan lain-lainnya yang cacat berat. Jizyah juga tidak wajib atas pendeta-pendeta di gereja kecuali jika mereka termasuk orang kaya.

\section{Besarnya Jumlah Pungutan}

Besarnya pungutan jizyah menurut Imam Hanafi dan Hanbali adalah sesuai dengan kemampuan orang yang dibebani, orang kaya diwajibkan 
membayar 48 dirham, kelas menengah diwajibkan baginya 24 dirham sedang orang fakir hanya diwajibkan 12 dirham saja. Ketentuan ini didasarkan apa yang dilakukan oleh Umar RA. (Wahab, 2004; 5886)

Imam Syafi'i berpendapat dan sebagian riwayat dari Ahmad: "Bahwasannya ada ketentuan minimal saja, yaitu satu dinar, adapun maksimal tidak ditentukan, hal ini diserahkan kepada ijtihad para gubernur". Pendapat Imam Malik dan salah satu riwayat dari Ahmad dan ini yang kuat: "Sesungguhnya tidak ada batas minimal dan batas maksimal, persoalannya diserahkan kepada ijtihad para gubernur untuk menentukan kewajiban bagi tiap-tiap pribadi sesuai dengan keadaannya". Tidak dibenarkan seseorang dibebankan di atas kemampuannya.

Ashab as-Sunan meriwayatkan dari Muaz RA bahwa Nabi SAW waktu mengutusnya ke Yaman memerintahkan agar ia memungut jizyah dari orang yang telah akil balig sebanyak satu dinar atau yang seharga $m u$ áfirah (Jenis pakaian di Yaman di ambil dari kata mu'ärifah sebuah distrik di Hamdan, Yaman).

Mengenai penggolongan istilah kaya, menengah dan miskin tidak ada bukti sejarah yang mengungkapkan mengenai hal ini. Akan tetapi, dalam penafsiran Al-Tahawi dinyatakan bahwa orang-orang yang memiliki 10.000 dirham atau lebih termasuk kategori orang kaya, sementara orang yang memiliki harta senilai 200 dirham ke atas di sebut golongan menengah, dan bagi orang yang memiliki kurang dari 200 dirham tergolong orang miskin. (M. A. Manan, 1992; 249)

Dengan adanya perbedaan besarnya jumlah jizyah yang di pungut dapat disimpulkan bahwa besarnya pungutan tergantung ijtihad para khalifah dan gubernur yang berkuasa di daerah kekuasaannya. Besarnya yang di ambil disesuaikan dengan kemampuan masing-masing individu, tidak ada batas minimal dan maksimal. Hanya saja Imam Syafi'i mengatakan batas minimal adalah satu dinar.

Adapun mengenai waktu pembayaran jizyah menurut Imam Hanafi, jizyah wajib di bayar pada awal tahun, karena untuk melindungi kaum Zhimmi di masa mendatang. Sedangkan selain Imam Hanafi, semua mazhab berpendapat bahwa jizyah di bayar pada akhir tahun jika sudah mencapai haul seperti halnya zakat. (Wahab, 2004; 5886)

\section{Penghentian Jizyah}

Jizyah tidak di pungut lagi bagi yang telah masuk Islam. Jadi, siapa saja yang memeluk Islam maka gugurlah kewajiban jizyah dari dirinya, baik ia masuk Islam pada awal tahun, pertengahannya, akhir tahun maupun telah lewat satu tahun. Tidak ada lagi kewajiban jizyah atasnya sedikit pun, karena Allah SWT berfirman:

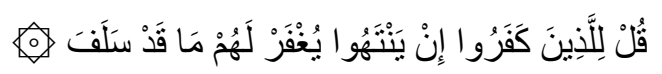


"Katakanlah kepada orang-orang yang kafir itu: "Jika mereka berhenti (dari kekafirannya), niscaya Allah akan mengampuni mereka tentang dosa-dosa mereka yang sudah lalu" (QS. Al-Anfāl: 38). Ibnu Abbas telah meriwayatkan dari

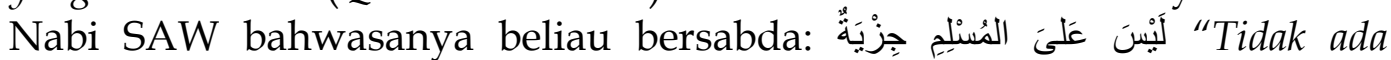
kewajiban jizyah bagi muslim".

Menurut kalangan Hanafiyah, Malikiyah dan Zaidiyah Jizyah gugur karena kematian. Karena, jizyah menurut pandangan mereka adalah hukuman. Sedang menurut golongan Syafi'iyah dan Hanabilah jizyah tidak gugur karena kematian. Maka harus di ambil dari harta peninggalannya. Karena, jizyah seperti halnya hutang yang harus di bayar.

\section{Hak dan Kewajiban Bagi Ahlu Zhimmah}

Setelah mereka membayar jizyah, kaum Muslim harus memenuhi hak-hak Ahlu Zhimmah. Di mana mereka memperoleh hak-haknya sebagai berikut:

1. Memelihara dan menjaga keputusan damai dengan Ahlu Zhimmah di negara Islam kecuali memasuki al-Haram (Mekah dan Madinah) menurut pandangan jumhūr ahli Fikih. Ini sesuai dengan Firman Allah,

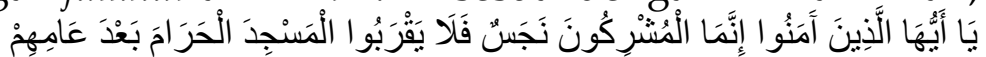
"Hai orang-orang yang beriman, Sesungguhnya orang-orang yang musyrik itu najis, maka janganlah mereka mendekati Masjidil Haram sesudah tahun ini" (QS. At-Taubah: 28). Yang di maksud adalah daerah Haram, dengan dalil firman Allah وَإِنْ خِفَتُمْ عَنْلَّةً "Dan jika kamu khawatir menjadi miskin" (QS. At-Taubah: 28). Sedang Imam Abu Hanifah membolehkan mereka untuk memasuki daerah Haram seperti semua daerah Hijaz, akan tetapi mereka tidak boleh bertempat tinggal di sana, larangan tidak boleh bertempat tinggal tidak menghalangi mereka memasuki daerah Haram.

Kalangan Malikiyah melarang mereka untuk berdomisili di Jazirah Arab yaitu Hijaz dan Yaman, akan tetapi mereka boleh memasuki daerah Haram kecuali Ka'bah. Sedang Hanabilah membolehkan mereka memasuki daerah Hijaz untuk berdagang dan tidak boleh tinggal di daerah Haram lebih dari tiga hari, ada juga yang mengatakan tidak boleh lebih dari empat hari.

Imam Syafi'i melarang dan mengharamkan mereka memasuki Mekah apapun keadaannya, jika mereka memasukinya dengan sembunyi-sembunyi dan ketahuan maka mereka wajib dikeluarkan. Dan jika mati dan dimakamkan di Mekah, maka makamnya harus di bongkar dan memindahkannya dari sana selama belum berubah.

2. Wajib menjaga dan melindungi mereka, karena kaum Muslimin telah mengadakan aqad (perjanjian) dengan mereka untuk melindungi jiwa dan harta mereka setelah membayar jizyah. Dan juga perang dengan 
mereka telah selesai. Ini sesuai dengan hadis yang diriwayatkan oleh Imam Muslim dari Buraidah RA,

فسلهم الجزية، فإن هم أجابوك فاقبل منهم و كفَّ عنهم

"Pungutlah jizyah dari mereka, jika mereka mematuhimu maka terimalah pemberian dari mereka dan lindungilah mereka".

Adapun kewajiban-kewajiban yang harus mereka lakukan menurut Wahbah Zuhaili diantaranya adalah sebagai berikut:

a. Setiap laki-laki yang akil balig diwajibkan membayar jizyah sekali dalam setahun yaitu satu dinar menurut Imam Syafi'i, dan jika dalam perjanjian damai ditentukan lebih dari satu dinar maka bolehboleh saja, sedang menurut jumhūr ahli Fikih empat dinar.

b. Menjamu kaum Muslimin selama tiga hari jika kaum Muslimin melewati (singgah) tempat tinggal mereka.

c. Membayar $10 \%$ dari dagangan mereka di selain negeri yang mereka tinggali.

d. Mereka tidak boleh membangun gereja dan meninggalkan bangunan di negeri yang di bangun oleh kaum Muslimin.

e. Mereka tidak boleh mengendarai kuda, bigāl yang bagus (binatang sejenis kuda kecil), dan mereka hanya boleh mengendarai keledai.

f. Mereka harus memakai 'alāmah (tanda) yang bisa mengenali mereka, seperti menggunakan sabuk atau gesper, dan menghukumnya jika tidak memakainya.

g. Mereka tidak boleh mencurangi kaum Muslimin, melindungi jasūs (mata-mata) dan tidak boleh bekerja sama dengan ahlu Harbi untuk menyakiti kaum Muslimin serta hal-hal lain yang dapat membahayakan kaum Muslimin.

h. Mereka tidak boleh menghalangi kaum Muslimin singgah atau tinggal sementara di tempat ibadah mereka baik siang maupun malam.

i. Menghormati kaum Muslimin, tidak boleh memukul, menghina dan memperkerjakan kaum Muslimin.

j. Mereka harus menyembunyikan lonceng dan tidak boleh menampakkan sesuatu yang menjadi ciri khas syi'ar-syi'ar agama mereka.

k. Tidak boleh mencela para Nabi AS, menampakkan keyakinan mereka, menghina syariat Allah Azza wa Jalla dan memperlihatkan rasa tidak suka terhadap Al-Qur`an dan Rasul SAW.

1. Mereka harus melaksanakan hukum Islam baik mu'amalah dan al'uqūbah al-jinā iyah, seperti mengharamkan zina dengan dalil bahwa Nabi SAW merajam seorang laki-laki dan perempuan Yahudi yang berzina. Mereka juga di larang melakukan riba, kemunkaran, 
maksiat dan hal-hal fasiq, akan tetapi mereka boleh minum khamar sesuai dengan keyakinan mereka.

\section{Penggunaan Jizyah}

Tidak ada perbedaan pendapat di kalangan kaum Muslim bahwa penggunaan jizyah sama seperti penggunaan fai yang berupa kharāj dan 'usyūr. Yaitu di simpan di baitul mal dan digunakan untuk kemaslahatan kaum Muslim, serta untuk keperluan jihād fi sabìlillāh. Hal ini dilakukan sesuai dengan ijtihad dan pendapat Khalifah dalam memelihara urusan kaum Muslim serta dalam rangka mewujudkan kemaslahatan mereka.

\section{Kritik Orientalis Tentang Jizyah}

Ada kritikan tentang pemungutan jizyah atas kalangan non Muslim. Untuk menjawab tuduhan Orientalis ini, penulis paparkan sanggahan yang penulis kutip dari M. A. Manan. (M.A Manan, 1992; 249) Sanggahan pertama, adalah tidak wajar untuk menganggap jizyah sebagai sewa dari pihak kalangan Zhimmi untuk berdiam di negara Muslim. Seandainya hal itu benar, maka wanita, anak-anak, orang yang sakit ingatan, dan orang-orang tua juga akan dikenakan pajak tersebut, tapi mereka tidak diharuskan membayar pajak ini. Maka, berarti kesejahteraan rakyatlah yang menjadi dasar dikenakannya jizyah atas kalangan non Muslim. Lagipula, jizyah bukanlah pajak represif. Pendapat ini disokong oleh Aghnides dalam Mohammedan Theories of Finance ketika ia menulis "Jizyah dikenakan oleh imam atas penduduk suatu wilayah yang ditaklukkan dengan kekuatan senjata".

Sanggahan kedua, pendapat ini adalah tidak benar. Karena, secara jelas konsep tentang jizyah didasarkan pada firman Allah dalam surat AtTaubah ayat 29. Istilah shāgirūn dalam ayat Al-Qur'an tersebut secara sederhana diartikan kepatuhan (submission). Pengertian itu didasarkan pada dua alasan. Pertama, karena semua orang laki-laki, perempuan, maupun anak-anak dibebaskan dari membayar jizyah. Kedua, penggunaan kekerasan atau kekuatan untuk memaksa keyakinan kepada orang lain adalah jelas di larang oleh kitab suci Al-Qur’an. Dengan demikian, M.A. Manan sependapat dengan Imam Syafi'i yang-berdasarkan pada kekuatan pendapat yang di pegang oleh sejumlah orang berpengetahuan menyimpulkan bahwa kepatuhan (ketundukan) yang di maksud oleh AlQur`an adalah bentuk kepatuhan orang kafir kepada aturan orang Islam atau hukum Islam, sehingga orang tidak boleh di golongkan kepada status Zhimmi kecuali dengan syarat tunduk kepada hukum Islam. Ketundukan janganlah diartikan dalam arti yang digunakan dalam usaha kehidupan biasa kita. Kekerasan dalam memperlakukan golongan Zhimmi selama proses pemungutan jizyah adalah bertentangan dengan jiwa Islam. 


\section{ANALISIS}

Kebijakan-kebijakan yang dicontohkan Rasulullah SAW baik masalah hukum, politik juga ekonomi menjadi pedoman bagi Khulafa arRasyidin, para sahabatnya yang tak kenal lelah selalu mendampingi beliau. Di antara kebijakan yang berkaitan dengan ekonomi adalah pemungutan 'usyūr dan jizyah. 'Usyūr dan jizyah adalah salah satu sumber pendapatan pada awal Islam yang cukup penting untuk keuangan negara. Kebijakan ini juga digunakan oleh pengikutnya dalam menata kehidupan ekonomi negara. Berdasarkan hal tersebut, pemerintah Islam mengambil manfaat dari 'usyūr dan jizyah untuk merealisasikan banyak tujuan dalam aktivitas ekonomi, diantaranya:

1. Pembatasan impor, yaitu dengan menaikan 'usyūr terhadap barangbarang impor yang tidak disukai untuk membatasinya. Sebaliknya, sangat memungkinkan untuk memotivasi impor barang-barang penting dengan menurunkan 'usyūr padanya, dan boleh jadi kemaslahatan kaum Muslimin menuntut penghapusan 'usyūr secara total. Sesungguhnya serampangan dalam mengimpor segala bentuk barang konsumsi bagi kaum Muslimin pada hari ini adalah yang menyebabkan mengakarnya sikap mengekor dalam ekonomi kaum Muslimin terhadap ekonomi lain, di mana produk-produk Barat telah menyerang daerah kaum Muslimin, sehingga kaum Muslimin menjadi tawanan model konsumsi non Muslim; karena perusahaan-perusahaan Barat tersebut menentukan bentuk pakaian dan kendaraan kaum Muslimin, bahkan banyak dari makanan mereka. Sebagaimana pasar kaum Muslimin juga telah tenggelam dengan barang-barang yang tidak bermanfaat dan mengeruk kekayaan kaum Muslimin. Oleh karena itu, negara Islam harus menggunakan politik 'usyūr dan politik lain yang berguna dalam membatasi barang-barang impor yang tidak disukai, dan memotivasi impor barang-barang yang memiliki kemaslahatan yang kuat bagi kaum muslimin.

2. Pengambilan 'usyīr dalam setiap tahun terhadap para pedagang non Muslim dapat memberikan kesempatan negara Islam untuk mengambil manfaat dari pengalaman-pengalaman non Muslim yang seringkali mengambil bentuk perusahaan non Islam yang pemasaran produksinya mendominasi di negara Islam, atau perusahaan non Islam yang memiliki kegiatan ekonomi di negara Islam, melakukan proses ekspor-impor, dan mematuhi apa yang di pandang oleh negara Islam dapat merealisasikan kemaslahatannya; dan negara Islam-dengan beranalogi pada 'usyūr - dapat menetapkan rencana tahunan kegiatan ekonomi bagi perusahaan tersebut, sehingga dapat berandil memberikan keuntungan yang didapatnya di bumi Islam. Urgensi hal tersebut nampak jelas pada masa sekarang sebagai sarana andilnya 
negara-negara Islam di dalam keuntungan besar yang di raih perusahaan-perusahaan non Islam yang diizinkan melakukan kegiatannya di daerah kaum Muslimin; yaitu dengan menetapkan bagian dari masuknya perusahaan tersebut untuk kemaslahatan negara Islam.

3. Dari segi persaudaraan universal Islam (Ukhuwwah Islämiyah) 'usyūr mungkin tidak dibenarkan untuk mengadakan rintangan dalam bidang perdagangan internasional, karena pada dasarnya Islam meyakini kesatuan kemanusiaan, dan karena itu pula perdagangan bebas. Tapi, di pandang dari segi kepentingan kelangsungan hidup suatu negara Islam miskin yang berkembang, sistem modern bea cukai dan tarif patut dipertahankan. Menurut M. A. Manan bahwa negara Islam berhak untuk mengenakan suatu jumlah bea cukai asal saja penghasilan ini digunakan untuk kesejahteraan masyarakat secara keseluruhan. Dan apapun tujuannya, hal itu tidak mendorong tumbuhnya suatu monopoli atau sejenisnya. Karenanya, petugas bea cukai harus orang yang jujur dan harus ada pengawasan yang ketat.

4. Dalam lingkungan sosial-ekonomi yang primitif dikenakannya jizyah mungkin adalah pilihan terbaik, karena hal ini konsisten dengan prinsip keadilan alami. Setiap warga negara harus membayar kewajibannya guna pemeliharaan keamanan dalam negeri dan pencegahan serbuan dari luar, tidak peduli apakah ia seorang Muslim atau non Muslim.

5. Islam mewajibkan jizyah bagi kaum Zhimmi sejalan dengan kewajiban kaum Muslimin mengeluarkan zakat, sehingga kedudukan keduanya ini sejajar. Karena, orang-orang Islam dan orang-orang Zhimmi bernaung di bawah satu bendera, dan mereka menikmati berbagai hak serta memperoleh manfaat dari negara secara sama. Karena itu, Allah mewajibkan jizyah di pungut oleh kaum Muslimin sebagai imbalan atas perlindungan bagi orang-orang Zhimmi di negara-negara Islam di mana mereka tinggal. Oleh karena itu, sesudah orang-orang Zhimmi mengeluarkan jizyah, kaum Muslimin wajib melindungi dan membela mereka dari orang yang bermaksud menyakiti mereka.(Sayyid, 1999; 442)

\section{KESIMPULAN}

'Usyūr dan jizyah adalah salah satu sumber pendapatan pada awal Islam yang cukup penting untuk keuangan negara. Kedua pajak ini telah di praktekkan pada zaman Khulafa ar-Rasyidin, para sahabatnya yang tak kenal lelah selalu mendampingi beliau. Kebijakan ini juga digunakan oleh pengikutnya dalam menata kehidupan ekonomi negara. 
Penulis ingin menekankan bahwa pemungutan 'usyūr dan jizyah adalah untuk kemaslahatan umat Islam pada waktu itu. Artinya, kebijakan itu dapat berubah sesuai dengan perubahan waktu dan tempat. Semisal dalam jumlah pungutan yang di ambil, kesemuanya itu tergantung ijtihad Khalifah dan sesuai dengan kemampuan pihak yang di pungut. 'Usyūr di ambil karena kalangan non Muslim mengambil pajak dari umat Islam yang berdagang ke daerah mereka. Di samping itu, pemungutan 'usyūr untuk menjaga stabilitas ekonomi dalam negeri negara Islam. Sedangkan pemungutan jizyah untuk menjaga dan melindungi jiwa dan harta ahlu Zhimmah yang tinggal di bawah naungan negara Islam.

\section{DAFTAR PUSTAKA}

Abdul Manan, Muhammad, (1992), Ekonomi Islam: Praktek dan Teori. Terj. Potan Arif Harahap. Jakarta: Intermasa.

an-Nabhani, Taqyuddin.(1996), Membangun Sistem Ekonomi Alternatif; Perspektif Islam, Terj. Moh. Maghfur Wachid. Surabaya: Risalah GustI

Antonio, Muhammad Syafi'I, (2007), Muhammad SAW: The Super Leader Super Manager. Jakarta: ProLM Centre.

Ibnu Ahmad al-Haris, Jaribah, (2006), Fikih Ekonomi Umar bin Al-Khattab. Terj. Asmuni Solihan Zamakhsyari. Jakarta: Kholifa.

Qadim Zallum, Abdul, (2002), Sistem Keuangan di Negara Khilafah. Terj. Ahmad S. dkk. Bogor: Pustaka Thariqul Izzah.

Sabahuddin, Azmi, (2005), Menimbang Ekonomi Islam: Keuangan Publik, Konsep Perpajakan, dan Peran Bait al-Mal. Terj. Widyawati. Bandung: Penerbit Nuansa

Sabiq, Sayyid, (1999), Fiqh as-Sunnah. al-Qāhirah: Dār al-Fath Lil I'lām al'Arabi.

Sami, al-Misri Abdul, (2006), Pilar-Pilar Ekonomi Islam. Terj. Dimyauddin Djuwaini. Yogyakarta: Pustaka Pelajar.

Sudarsono, Heri, (2007), Konsep Ekonomi Islam Suatu Pengantar. Yogyakarta: EKONISIA.

Warson Munawwir, Ahmad, (1997), Al-Munawwir Kamus Arab-Indonesia. Surabaya: Pustaka Progressif.

Zuhaili, Wahbah, (2004), Al-Fiqh al-Islāmi wa Adillatuhu. Dimasyq: Dār alFikr. 